\title{
Ende Diabetes Study: diabetes and its characteristics in rural area of East Nusa Tenggara
}

\author{
Sarwono Waspadji, ${ }^{1}$ Pradana Soewondo, ${ }^{1}$ Imam Subekti, ${ }^{1}$ Suharko Soebardi, ${ }^{1}$ Dante S. Harbuwono, ${ }^{1}$ \\ Laurentius A. Pramono, ${ }^{1}$ Taniawati Supali ${ }^{2}$ \\ ${ }^{1}$ Department of Internal Medicine, Faculty of Medicine, Universitas Indonesia, Jakarta, Indonesia \\ ${ }^{2}$ Center Research for Infectious Disease and Tropical Medicine, Faculty of Medicine, Universitas Indonesia, Jakarta, Indonesia
}

\begin{abstract}
Abstrak
Latar belakang: Penelitian diabetes di daerah rural Indonesia masih sangat sedikit. Hasil suatu penelitian epidemiologi komunitas diperlukan untuk pengambilan kebijakan penanggulangan penyakit di suatu daerah. Penelitian ini bertujuan untuk mengetahui prevalensi diabetes serta pengetahuan masyarakat di Kecamatan Nangapanda, Kabupaten Ende, Nusa Tenggara Timur.

Metode: Penelitian potong lintang "Ende Diabetes Study" dilaksanakan di Kecamatan Nangapanda, Kabupaten Ende untuk memperoleh prevalensi diabetes dan pengetahuan masyarakat tentang diabetes. Penelitian ini menggunakan metode cluster random sampling terhadap total penduduk Kecamatan Nangapanda yang berjumlah 19,756 jiwa. Dari kerangka sampel sebanyak 1800 subjek dewasa yang diskrining pada tahun 2008 dan 2009, sebanyak 125 subjek terdiagnosis sebagai diabetes atau GDPT (glukosa darah puasa terganggu). Seluruh subjek yang terdiagnosis diabetes dan GDPT masuk dalam penelitian ini, ditambah 218 subjek yang pada skrining 2008 dan 2009 memiliki kadar glukosa darah normal. Setiap subjek penelitian menjalani anamnesis umum, wawancara (anamnesis) nutrisi, pemeriksaan fisis lengkap, dan pemeriksaan laboratorium (darah dan urin). Data-data yang diperoleh dianalisis menggunakan SPSS 13.0.

Hasil: Sebanyak 343 subjek terlibat dalam penelitian ini. Prevalensi diabetes menggunakan kriteria kadar glukosa darah puasa atau kadar GD2PP (glukosa darah 2 jam pasca-pembebanan) pada penduduk Nangapanda adalah $2 \%$, dengan kriteria glukosa darah 2 jam pasca-pembebanan didapatkan prevalensi sebesar 1,56\%, sementara menggunakan tolok ukur HbAlc adalah 2,83\%. Prevalensi TGT (toleransi glukosa terganggu) 2,2\%, sementara GDPT (glukosa darah puasa terganggu) 6,2\%. Sebanyak 71,1\% penduduk Nangapanda memiliki pengetahuan yang cukup mengenai diabetes.
\end{abstract}

Kesimpulan: Prevalensi diabetes pada penduduk Nangapanda adalah 2\% (memakai kriteria glukosa darah puasa atau 2 jam pasca-beban glukosa) dan 1,56\% dengan kriteria 2 jam pasca-beban glukosa. Sebanyak 71,1\% penduduk Nangapanda memiliki pengetahuan yang cukup mengenai diabetes. (Med J Indones. 2013;22:30-8)

\begin{abstract}
Background: There are only few studies about diabetes in rural area in Indonesia. Epidemiological study are needed to formulate health policy of disease management in specific area. The aim of this study was to find the prevalence of diabetes and knowledge of diabetes among the community in Nangapanda Village, Ende District, East Nusa Tenggara.

Methods: A cross-sectional study "Ende Diabetes Study" was conducted in Nangapanda Village. This study use cluster random sampling method to a total number of 19756 residents in Nangapanda village. From the sampling frame of 1800 adult subjects who underwent screening with glucometer in 2008 and 2009, 125 subjects have been diagnosed as diabetes or impaired fasting glucose (IFG). All of the subjects who were diagnosed as diabetes or IFG from the previous screening and 218 subjects from control (normal subjects in the 2008 and 2009 screening) were included in the present study. Each subject underwent general anamnesis, nutritional interview, complete physical examinations, and laboratory test (blood and urine). The data were analyzed using SPSS 13.0.

Results: There were 343 subjects in this study. The prevalence of diabetes in Nangapanda using blood glucose criteria (using fasting and post-glucose load values) was $2 \%$; using post glucose load criteria, the prevalence of DM was $1.56 \%$; while with $\mathrm{HbA} 1 \mathrm{c}$ criteria, the prevalence was $2.83 \%$. The prevalence of impaired glucose tolerance (IGT) was $2.2 \%$, and IFG was $6.2 \%$. A number of $71.1 \%$ Nangapanda residents have sufficient knowledge about diabetes.

Conclusion: Prevalence of diabetes in Nangapanda (using fasting and post-glucose load criteria) was $2 \%$ and $1.56 \%$ (using post-glucose load values). As much as $71.1 \%$ of Nangapanda residents have sufficient knowledge about diabetes. (Med J Indones. 2013;22:30-8)
\end{abstract}

Keywords: Diabetes mellitus, Ende Diabetes Study, prevalence, rural Indonesia,

The increase of diabetes mellitus (DM) prevalence in various countries indicates that DM has become a global threat for the society worldwide. ${ }^{1}$ The diabetes prevalence in the world is $6.4 \%$; with the projection to be $7.7 \%$ in $2030 .{ }^{2}$ Southeast Asia has higher prevalence than the global average, which is $7.6 \%$. About $50 \%$ of the global diabetes load is in Asia. ${ }^{3}$ From the IDF global diabetes burden map, it can be estimated that both developing and under-developed countries, are areas which are going to have a higher raise in the prevalence of DM. ${ }^{2}$ This is due to the people's change of life-style, from traditional to modern society. 
The life-style changes toward modern unhealthy lifestyles is related to the life in urban areas, urbanization, and globalization. The diabetes prevalence in urban population tends to be higher than it is in the rural areas. Study made by Mohan et $\mathrm{al}^{4}$ showed that in India, the diabetes prevalence was the highest in urban community $(7.3 \%)$, followed by sub-urban $(3.2 \%)$, and rural community $(3.1 \%)$. Al-Nozha et $\mathrm{al}^{5}$ also found that in Saudi Arabia, the diabetes prevalence in urban areas was higher (25.5\%) than in communities who live in rural areas $(9.5 \%)$.

Indonesia is one of the countries in Asia which carries the greatest burden. Report from the National Basic Health Study in 2007 revealed that diabetes prevalence in Indonesia (age $>15$ year) was $5.7 \%$, while prediabetes prevalence (IGT or Impaired Glucose Tolerance) was $10.2 \%{ }^{6}$ Pre-diabetes prevalence in Jakarta in the study among residents in five Jakarta municipalities was $24.9 \%$, subdivided into IGT (17.9\%) and IFG (Impaired Fasting Glucose) $(7.0 \%){ }^{7}$ Community study at Koja Utara sub-district Jakarta in 1982 revealed that the diabetes prevalence was $1.7 \%,{ }^{8}$ while in Kayu Putih sub-district Jakarta (1993) the figure was $5.7 \% .^{9}$ A different study reported diabetes prevalence in Manado City was $6.1 \% .^{10}$

Study about urban community's risks for the development of diabetes can lead us to misunderstanding, if the rural community's risks and their specific condition not taken into account. This tends to reduce the concern of diabetes burden in rural areas. In Indonesia the amount of population studies on diabetes are more related to urban than rural areas. Even the 2008 National Basic Health Survey took samples from urban areas only. Several obstacles for conducting a diabetes study in rural areas are lack of tools and infrastructures for diagnosis, geographic challenges and the lack of interest to the problem of diabetes in rural areas.

Sub-urban Jakarta study at Depok (now become a town) in 2001 revealed that diabetes prevalence was $12.8 \%$. In the mean time, pre-diabetes prevalence at Depok (IGT and IFG combined) was $33.6 \% .^{11}$ Roesli conducted a diabetes study in rural areas at Singaparna, West Java, revealed that the diabetes prevalence was only $1.1 \%{ }^{12}$ Another study in semi-rural area, conducted by Suastika, at Sangsit Village, Bali Province, showed that the diabetes prevalence was $7.2 \%{ }^{13}$ Adam conducted diabetes study in Tana Toraja, in Celebes, and found that the diabetes prevalence was only $0.9 \% .{ }^{14}$

This study was about prevalence of diabetes mellitus, patients characteristics, diabetes complication, life style, and knowledge of the community in Nangapanda, Ende District, East Nusa Tenggara. The objectives of the study were (1) to have knowledge about diabetes prevalence and cardio-metabolic risk on the residents of Nangapanda, (2) to know about demographic factors related to diabetes prevalence, and (3) to know about the knowledge, attitude, behavior, and the life style of the community in Nangapanda in relation to diabetes and its management.

East Nusa Tenggara Province is one of poorest provinces in Indonesia. The results of this study will enrich diabetes map in Indonesia, besides, it will also make the Nangapanda community understand the importance of diabetes prevention, early diagnosis, and the appropriate management of diabetes. In this study, the team of researchers also had already implemented education program and short term medication in the location of the study.

\section{METHODS}

\section{Study design}

A cross-sectional study was carried out during March 2010 , to obtain the prevalence of diabetes mellitus, patient characteristics, risk factors, and the level of knowledge, attitude, and behavior of the community towards diabetes. The data collected were sociodemographic characteristics, physical examinations, fasting blood glucose and blood glucose two-hour after-75 gram glucose load, HbA1c, diet characteristics, attitude, and behavior of the community towards diabetes and its management.

\section{Location}

The study location was in Nangapanda Sub-district, Ende, Flores Island, East Nusa Tenggara Province. The majority of residents on Ende work in agricultural and fishery sectors since its border is Sawu Sea in the south side. In Nangapanda Sub-district, there are 17 villages. The size of the area is $213.7 \mathrm{~km} 2$. The amount of the adult residents in Nangapanda sub-district is 19756.

\section{Study population}

The study used cluster random sampling method by means of sample framework of the adult residents (age $>15$ year). In 2008-2009, 1800 Nangapanda residents were screen by glucometer with the result 125 subjects diagnosed to have IFG (impaired fasting glucose) or diabetes (DM). All of them were recruited for this study. In addition to that $13 \%$ from the original screening subjects who had normal blood glucose (1675 subjects) 


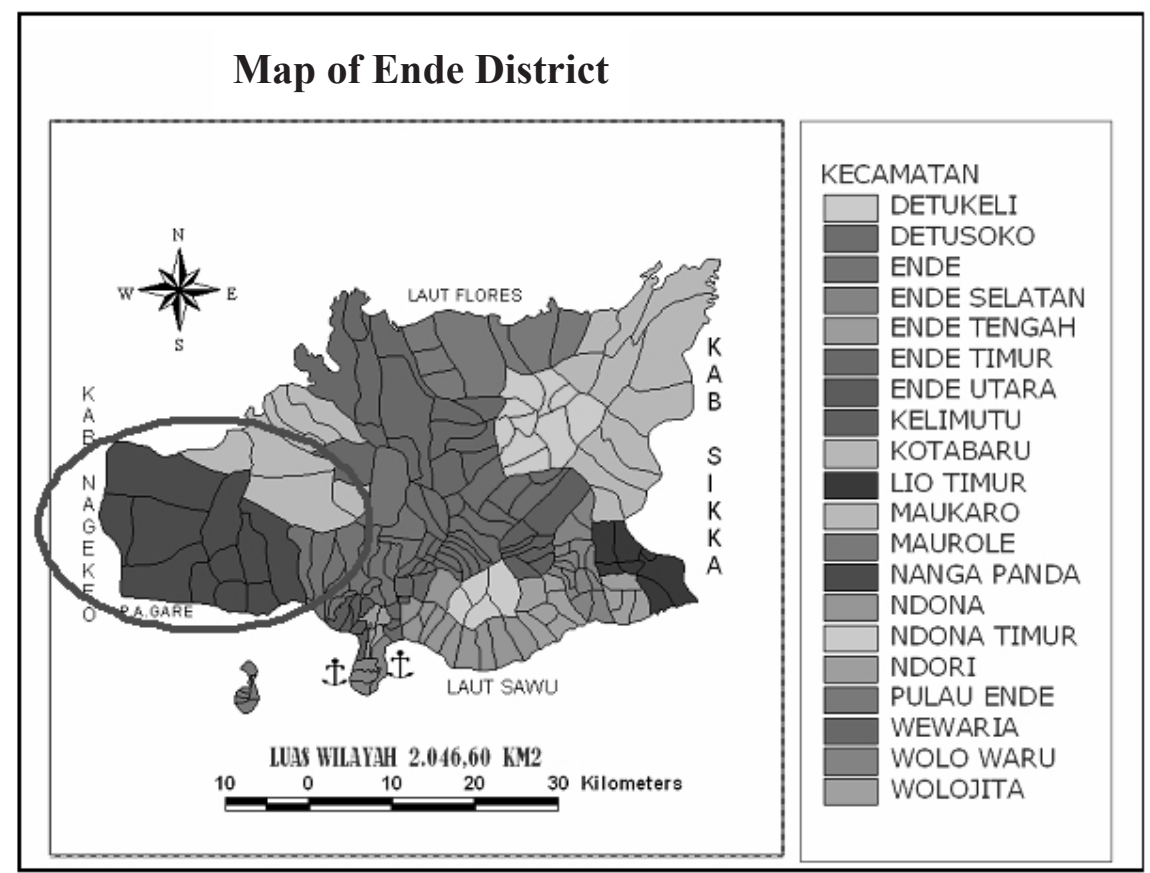

Figure 1. Ende map, East Nusa Tenggara Province (circle: Nangapanda sub-district) (Source: Health Section Ende District, 2010)

were also recruited (Figure 2). The addition of 13\% from normal population is to prevent underestimation of diabetes prevalence from only positive-screening result, based on Kelly West's theory about preventing common mistakes of false negative result from screening. ${ }^{15} \mathrm{In}$ this study, we have more than $13 \%$ subjects from normal population (218 subjects) to prevent drop out and higher the sensitivity of the research.

The respondents were asked to present at the specified post in the end of 12 hours fasting. Pre-trained enumerators recruited from medical personnel (doctors and nurses), as well as local cadre health personnel took health history with specific study forms. Physical examination was done by two doctors on duty in Nangapanda Public Health Center. Nutrition interview was done by registered dietician from Nutrition Unit Cipto Mangunkusumo Hospital Jakarta. Blood sample was drawn during fasting and 2 hours after 75 gram glucose load (2hPPG). Urine sample was also collected the same time. Blood glucose and urinary albumin was measured in Ende Public Hospital. Some of the fasting blood sample were sent to Department of Clinical Pathology Cipto Mangunkusumo Hospital Jakarta and test for HbAlc level as well as lipid profile (totalcholesterol, LDL-cholesterol, HDL-cholesterol and triglyceride levels).

Using the WHO 1999 and American Diabetes Association 2003 criteria DM is define if the fasting glucose $\geq 126 \mathrm{mg} / \mathrm{dL}$ or $2 \mathrm{hPPG} \geq 200 \mathrm{mg} / \mathrm{dL}$ or if $\mathrm{HbA} 1 \mathrm{c} \geq 6.5 \% .{ }^{16,17}$ The prediabetes using glucose

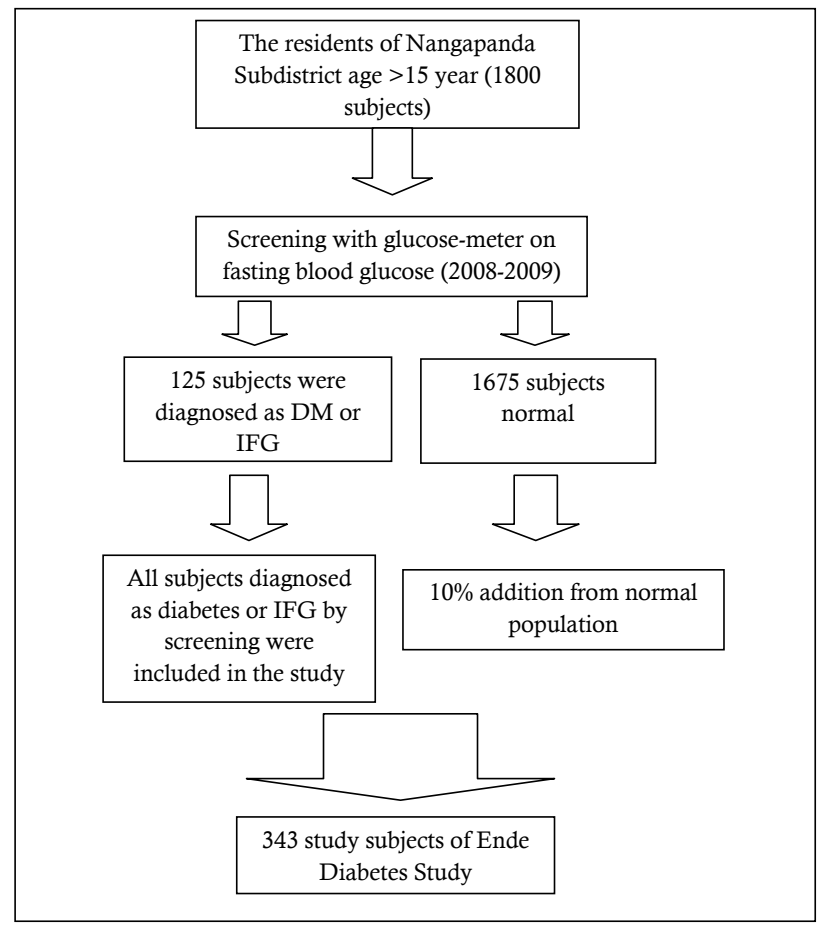

Figure 2. Study subjects of Ende diabetes study

level consists of Impaired Fasting Glucose (IFG) and Impaired Glucose Tolerance (IGT). IFG is defined as abnormal level of glucose on fasting ( $\geq 100 \mathrm{mg} / \mathrm{dL}-<$ $126 \mathrm{mg} / \mathrm{dL}$ ) while IGT is defined as abnormal glucose level after oral glucose load $(\geq 140 \mathrm{mg} / \mathrm{dL}-<200$ $\mathrm{mg} / \mathrm{dL}$ ). Prediabetes is also defined by $\mathrm{HbA} 1 \mathrm{c}$ level between $\geq 5.7 \%-<6.5 \%$. All criteria has been adapted by Indonesian Society for Endocrinologists. 


\section{Data analysis}

All data collected in this study were coded and processed by SPSS 13.0 program. The results were presented as percentage or 2 by 2 tables without statistical tests.

\section{RESULTS}

There were 343 subjects participating in this study.

\section{Subject characteristics}

The following data showed socio-demographic characteristics of the study subjects (Table 1).

More than half of subject was males (62.3\%). Most of them were adults ranging from 45 to 54 year (30.9\%). The educational level and socio-economic status of a considerable part of them were low, i.e. elementary school drop outs or illiterate $(37 \%)$ and of low socio economic level with the income of < IDR 1000,000/ month $(67.6 \%)$.

Most of the subjects had normal BMI (38.5\%), nevertheless a small part of them were overweight $(18.1 \%)$, while combination of obesity grade 1 and grade 2 was found in $30.3 \%$ of the subjects. Based on waist circumference, women have central obesity more than men (55\% vs. 10.3\%). Physical activities and knowledge about diabetes were good for both subjects. Meanwhile, there was fairly large amount suffered from hypertension (36.8\%) and pre-hypertension (39.4\%).

\section{Diagnosis of Diabetes, IGT, and IFG}

Diabetes prevalence is calculated from the subject who has $2 \mathrm{hPPG}$ value $\geq 200 \mathrm{mg} / \mathrm{dL}$ overtotal number of screened resident, and it was 28/1800 (1.56\%). Subjects who have fasting blood glucose $\geq 126 \mathrm{mg} / \mathrm{dL}$ was $29 / 1800=1.61 \%$. There were $36 / 1800(2 \%)$ who have met diabetes fasting glucose and post glucose load. IFG prevalence was $112 / 1800(6.2 \%)$ while IGT prevalence was $40 / 1800(2.2 \%)$.

The subject who has a good glycemic control was $83.7 \%$, a moderate glycemic control was $4.7 \%$ and a poor glycemic control was $10.2 \%$. Diabetes prevalence based on the value of A1c was 51/1800 (2.83\%).

\section{Lipid profile}

Dyslipidemia is related to the occurrence of diabetes as well as prediabetes, either as a risk factor or as comorbid. The proportion of the subjects with normal LDLcholesterol $(<130 \mathrm{mg} / \mathrm{dL})$ and normal triglyceride
Table 1. Characteristics of the subjects

\begin{tabular}{|c|c|c|}
\hline Subject Characteristics & Total & $\%$ \\
\hline \multicolumn{3}{|l|}{ Sex } \\
\hline Female & 129 & 37.6 \\
\hline Male & 214 & 62.3 \\
\hline \multicolumn{3}{|l|}{ Age } \\
\hline $15-24$ years-old & 9 & 2.6 \\
\hline $25-34$ years-old & 36 & 10.5 \\
\hline $35-44$ years-old & 96 & 28.0 \\
\hline $45-54$ years-old & 106 & 30.9 \\
\hline 55-64 years-old & 67 & 19.5 \\
\hline $65-74$ years-old & 21 & 6.1 \\
\hline 75-84 years-old & 8 & 2.3 \\
\hline \multicolumn{3}{|l|}{ Education } \\
\hline Unfinished elementary or illiterate & 127 & 37 \\
\hline Graduated from Elementary School & 80 & 23.3 \\
\hline Graduated from High School & 101 & 29.4 \\
\hline Higher Education & 35 & 10.2 \\
\hline \multicolumn{3}{|l|}{ Income Status } \\
\hline$<$ IDR $1000,000 /$ month & 227 & 67.6 \\
\hline IDR $1-3000,000 /$ month & 75 & 22.3 \\
\hline IDR 3-5000,000/month & 23 & 6.8 \\
\hline$>$ IDR $5000,000 /$ month & 11 & 3.3 \\
\hline \multicolumn{3}{|l|}{ Body Mass Index (BMI) } \\
\hline$<18.5$ (low) & 39 & 11.4 \\
\hline $18.5-22.9$ (normal) & 132 & 38.5 \\
\hline 23-24.9 (overweight) & 62 & 18.1 \\
\hline $25-30$ (obesity 1$)$ & 89 & 25.9 \\
\hline$>30($ obesity 2$)$ & 15 & 4.4 \\
\hline \multicolumn{3}{|l|}{ Waist Circumference } \\
\hline \multicolumn{3}{|l|}{ Male } \\
\hline$\leq 90 \mathrm{~cm}$ & 192 & 89.7 \\
\hline$>90 \mathrm{~cm}$ & 22 & 10.3 \\
\hline \multicolumn{3}{|l|}{ Female } \\
\hline$\leq 80 \mathrm{~cm}$ & 58 & 45 \\
\hline$>80 \mathrm{~cm}$ & 71 & 55 \\
\hline \multicolumn{3}{|l|}{ Physical Activity (hour/week) } \\
\hline$<4$ hour/week & 112 & 32.7 \\
\hline$>4$ hour/week & 231 & 67.3 \\
\hline \multicolumn{3}{|l|}{ Blood Pressure } \\
\hline Normal & 82 & 23.9 \\
\hline Pre-hypertension & 135 & 39.4 \\
\hline Hypertension grade 1 & 65 & 19.0 \\
\hline Hypertension grade 2 & 61 & 17.8 \\
\hline \multicolumn{3}{|l|}{ Knowledge about Diabetes } \\
\hline Sufficient & 244 & 71.1 \\
\hline Not sufficient & 99 & 28.9 \\
\hline
\end{tabular}

(<200 mg/dL) were fairly high, $62.7 \%$ and $87.5 \%$ respectively, while only $37 \%$ of subjects had high LDL-cholesterol level (> $130 \mathrm{mg} / \mathrm{dL})$ and $12.3 \%$ high triglyceride $(>200 \mathrm{mg} / \mathrm{dL})$. A few subjects $(1.2 \%)$ had an extremely high level of trigliceride $(\geq 400 \mathrm{mg} / \mathrm{dL})$. The proportion of subjects with total cholesterol level above $200 \mathrm{mg} / \mathrm{dL}$ was $47.2 \%$. The problem can be seen on HDL-cholesterol level, i.e. only $28.1 \%$ woman and 21.3\% men have desirable HDL-cholesterol level ( $>50$ $\mathrm{mg} / \mathrm{dL}$ for woman or $40 \mathrm{mg} / \mathrm{dL}$ for man) (Table 3). 
Table 2. Blood glucose and HbA1c distribution among study subjects (Normal, IFG, IGT, and DM)

\begin{tabular}{ccc}
\hline \multicolumn{1}{c}{ Variables } & Total & Percentage \\
\hline FBG (fasting blood glucose) & & \\
$<100 \mathrm{mg} / \mathrm{dL}$ & 201 & 58.7 \\
$100-125 \mathrm{mg} / \mathrm{dL}$ & 112 & 32.7 \\
$\geq 126 \mathrm{mg} / \mathrm{dL}$ & 29 & 8.5 \\
$2 \mathrm{hrs}$ Post Load & & \\
$<140 \mathrm{mg} / \mathrm{dL}$ & 274 & 80.1 \\
$140-199 \mathrm{mg} / \mathrm{dL}$ & 40 & 11.7 \\
$\geq 200 \mathrm{mg} / \mathrm{dL}$ & 28 & 8.2 \\
$\mathrm{HbA} 1 \mathrm{c}$ & & \\
$<6.5 \%$ & 287 & 83.7 \\
$6.5-8 \%$ & 16 & 4.7 \\
$>8 \%$ & 35 & 10.2 \\
\hline
\end{tabular}

Total diabetes subjects (based on $\mathrm{FBG} \geq 126 \mathrm{mg} / \mathrm{dL}$ and $2 \mathrm{hPPG}$ $\geq 200 \mathrm{mg} / \mathrm{dL})=36$

\section{Specific distribution according to socio-demographic factor and risk factors}

There was no age specific pattern for the distribution of normal blood glucose as well as blood glucose values for IFG and IGT. However the percentage of DM was higher in older age group.

The distribution of diabetes mellitus was higher among females $(13.95 \%)$ compared to their male counterpart $(4.7 \%)$. The condition were also true for IFG and IGT. DM was more commonly found among the higher education level group (17.1\%) compared to the lower education level group. For IFG and IGT there were no specific preference for the different level of education. Diabetes mellitus, IFG and IGT were less commonly found in the low income group $(5.3 \%, 30.4 \%$, and $7.5 \%$ respectively) compared to the medium and higher income group $(14.7 \%, 35.3-$ $41.3 \%$, and $20.5-21.3 \%$ respectively). There was no differences of knowledge about diabetes among different blood glucose levels.

Daily activity is considered to be one of the important risk factors for the development of diabetes mellitus and other glucose intolerance. In this study, among the DM groups the number of subjects with less physical activity was more pronounced compared to those with more active one (12.5 vs. $6.1 \%)$. Obesity is also considered to be the most important factors for the development of insulin resistance, IGT as well as diabetes mellitus. In this study, IFG, IGT and DM were more frequent in the higher BMI groups. The proportion of IFG, IGT and DM was high among the obese group (40.4\%, 18.3\%, and $13.5 \%$ respectively). There was no specific blood
Table 3. Lipid profile among subjects of Ende Diabetes Study

\begin{tabular}{llcc}
\hline Lipid profile & Range & Total & Percentage \\
\hline LDL-chol & $<70 \mathrm{mg} / \mathrm{dL}$ & 9 & 2.6 \\
& $70-99 \mathrm{mg} / \mathrm{dL}$ & 76 & 22.2 \\
& $100-129 \mathrm{mg} / \mathrm{dL}$ & 130 & 37.9 \\
& $130-159 \mathrm{mg} / \mathrm{dL}$ & 78 & 22.7 \\
& $\geq 160 \mathrm{mg} / \mathrm{dL}$ & 49 & 14.3 \\
HDL-chol (male) & $>40 \mathrm{mg} / \mathrm{dL}$ & 45 & 21.3 \\
HDL-chol (female) & $>50 \mathrm{mg} / \mathrm{dL}$ & 166 & 78.7 \\
& $\leq 50 \mathrm{mg} / \mathrm{dL}$ & 92 & 71.9 \\
Triglyceride & $<150 \mathrm{mg} / \mathrm{dL}$ & 237 & 69.1 \\
& $150-199 \mathrm{mg} / \mathrm{dL}$ & 63 & 18.4 \\
& $200-399 \mathrm{mg} / \mathrm{dL}$ & 38 & 11.1 \\
& $\geq 400 \mathrm{mg} / \mathrm{dL}$ & 4 & 1.2 \\
& $<170 \mathrm{mg} / \mathrm{dL}$ & 79 & 23.0 \\
& $170-199 \mathrm{mg} / \mathrm{dL}$ & 102 & 29.7 \\
& $200-239 \mathrm{mg} / \mathrm{dL}$ & 107 & 31.2 \\
& $\geq 240 \mathrm{mg} / \mathrm{dL}$ & 55 & 16.0 \\
\hline
\end{tabular}

pressure level for the normal, IFG, IGT as well as for the DM groups.

Distribution of HbAlc levels among all the groups did not show specific pattern. Even among the normal group (according to blood glucose level) there were $40.0 \%$ who had $\mathrm{HbA} 1 \mathrm{c}$ level $>8 \%$. Similar irregularities and discrepancy can also be seen in IFG, IGT and DM groups.

\section{DISCUSSION}

This is the first prevalence study which aim to describe prevalence and characteristics of diabetes in rural Indonesia. With logistic limitation, this study was able to yield a lot of informations, either about health or laboratory profile.

\section{Diabetes in rural areas}

Prevalence of diabetes in rural areas varies between countries, as well as between provinces or between areas in one country. It is influenced by several determinants, i.e. economic growth, socio-cultural condition, modernization, and urbanization. ${ }^{18}$ Many Asian countries (developing countries), which in the last decade tend to have a very fast socio-economiccultural growth, have a high increase in the prevalence of diabetes. ${ }^{18-19}$ Balagopal et $\mathrm{al}^{19}$ mentioned that the prevalence of diabetes in Indian rural areas was 5.1\% and $13.1 \%$. Syeed et al ${ }^{18}$ also reported the similar number. There was an increase in the prevalence of diabetes $(4.3 \%)$ as well as IFG (12.4\%) in Bangladesh 
Table 4. Variables - specific distribution of glucose intolerance

\begin{tabular}{|c|c|c|c|c|}
\hline Variables & Normal & IFG & IGT & $\mathrm{DM}$ \\
\hline \multicolumn{5}{|l|}{ Age } \\
\hline $15-24$ years-old $(n=9)$ & $5(55.6 \%)$ & $4(44.4 \%)$ & $2(22.2 \%)$ & 0 \\
\hline $25-34$ years-old $(n=36)$ & $24(66.6 \%)$ & $12(33.3 \%)$ & $3(8.3 \%)$ & 0 \\
\hline $35-44$ years-old $(n=96)$ & $63(65.6 \%)$ & $29(30.2 \%)$ & $10(10.4 \%)$ & $4(4.2 \%)$ \\
\hline $45-54$ years-old $(n=106)$ & $60(56.6 \%)$ & $36(34 \%)$ & $9(8.5 \%)$ & $10(9.4 \%)$ \\
\hline $55-64$ years-old $(n=67)$ & $34(50.7 \%)$ & $20(29.9 \%)$ & $9(13.4 \%)$ & $13(19.4 \%)$ \\
\hline $65-74$ years-old $(n=21)$ & $12(57.1 \%)$ & $8(38.1 \%)$ & $5(23.8 \%)$ & $1(4.8 \%)$ \\
\hline $75-84$ years-old $(n=8)$ & $5(62.5 \%)$ & $3(37.5 \%)$ & $2(25 \%)$ & 0 \\
\hline \multicolumn{5}{|l|}{ Gender } \\
\hline Female $(\mathrm{n}=129)$ & $42(32.6 \%)$ & $69(53.5 \%)$ & $17(13.2 \%)$ & $18(13.95 \%)$ \\
\hline Male $(n=214)$ & $161(75.2 \%)$ & $43(20.1 \%)$ & $23(10.7 \%)$ & $10(4.7 \%)$ \\
\hline \multicolumn{5}{|l|}{ Education } \\
\hline Unfinished elementary or illiterate $(n=127)$ & $75(59.1 \%)$ & $42(33.1 \%)$ & $11(8.7 \%)$ & $10(7.9 \%)$ \\
\hline Elementary school $(n=80)$ & $47(58.8 \%)$ & $29(36.3 \%)$ & $10(12.5 \%)$ & $4(5 \%)$ \\
\hline High school $(\mathrm{n}=101)$ & $66(65.3 \%)$ & $27(26.7 \%)$ & $14(13.9 \%)$ & $8(7.9 \%)$ \\
\hline Higher education $(\mathrm{n}=35)$ & $15(42.9 \%)$ & $14(40 \%)$ & $5(14.2 \%)$ & $6(17.1 \%)$ \\
\hline \multicolumn{5}{|l|}{ Socio-Economic status (income) } \\
\hline$\leq$ IDR $1000,000 /$ month $(\mathrm{n}=227)$ & $146(64.3 \%)$ & $69(30.4 \%)$ & $17(7.5 \%)$ & $12(5.3 \%)$ \\
\hline IDR $1-3000,000 / \operatorname{month}(\mathrm{n}=75)$ & $33(44 \%)$ & $31(41.3 \%)$ & $16(21.3 \%)$ & $11(14.7 \%)$ \\
\hline$>$ IDR $3000,000 /$ month $(\mathrm{n}=34)$ & $17(50 \%)$ & $12(35.3 \%)$ & $7(20.5 \%)$ & $5(14.7 \%)$ \\
\hline \multicolumn{5}{|l|}{ Knowledge } \\
\hline Sufficient $(n=244)$ & $136(55.7 \%)$ & $84(34.4 \%)$ & $28(11.5 \%)$ & $24(9.8 \%)$ \\
\hline Not sufficient $(\mathrm{n}=99)$ & $67(67.8 \%)$ & $28(28.3 \%)$ & $12(12.1 \%)$ & $4(4 \%)$ \\
\hline \multicolumn{5}{|l|}{ Physical activity } \\
\hline$<4$ hours/week $(\mathrm{n}=112)$ & $66(58.9 \%)$ & $32(28.6 \%)$ & $13(11.6 \%)$ & $14(12.5 \%)$ \\
\hline$>4$ hours/week $(\mathrm{n}=231)$ & $137(59.3 \%)$ & $80(34.6 \%)$ & $27(11.7 \%)$ & $14(6.1 \%)$ \\
\hline \multicolumn{5}{|l|}{ BMI } \\
\hline$<18.5(\mathrm{n}=39)$ & $27(69.2 \%)$ & $11(28.2 \%)$ & $6(15.4 \%)$ & $1(2.6 \%)$ \\
\hline $18.5-22.9(\mathrm{n}=132)$ & $88(66.7 \%)$ & $38(28.8 \%)$ & $8(6.1 \%)$ & $6(4.5 \%)$ \\
\hline $23.0-24.9(\mathrm{n}=62)$ & $38(61.3 \%)$ & $19(30.6 \%)$ & $6(9.7 \%)$ & $5(8.1 \%)$ \\
\hline$\geq 25(\mathrm{n}=104)$ & $48(46.2 \%)$ & $42(40.4 \%)$ & $19(18.3 \%)$ & $14(13.5 \%)$ \\
\hline \multicolumn{5}{|l|}{ Blood pressure } \\
\hline Normal $(\mathrm{n}=82)$ & $44(53.7 \%)$ & $28(34.1 \%)$ & $15(18.3 \%)$ & $10(12.2 \%)$ \\
\hline Pre-hypertension $(\mathrm{n}=135)$ & $85(63.0 \%)$ & $46(34.1 \%)$ & $10(7.4 \%)$ & $4(3.0 \%)$ \\
\hline Hypertension grade $1(n=65)$ & $34(52.3 \%)$ & $24(36.9 \%)$ & $7(10.8 \%)$ & $7(10.8 \%)$ \\
\hline Hypertension grade $2(n=61)$ & $40(65.6 \%)$ & $14(23.0 \%)$ & $8(13.1 \%)$ & $7(11.5 \%)$ \\
\hline
\end{tabular}

rural areas. High socio-economic class, history of diabetes in family, lack of physical activities, increasing of age, BMI, and waist-circumference were important predictors for diabetes occurrence in Bangladesh rural areas.

The changing pattern from normal subject to prediabetes, then to diabetes are extremely influenced by changes from normal BMI to obesity, along with the change of the dietary composition of the community. This pattern of development could also be seen in this study. Among the obese group, the proportion of IFG, IGT and especially DM wass higher compare to those with lower BMI. The total calorie intake as well as the dietary pattern in this rural area was similar to the total calorie intake and dietary composition in urban area Jakarta about 30 years back (1981-1982).
South African rural society also has a significant increase in epidemic of diabetes. Motala et $\mathrm{al}^{20}$ showed that the prevalence of diabetes, IFG, and IGT was 3.9\%, $1.5 \%$, and $4.8 \%$ respectively. Diabetes occurrence and pre-diabetes was positively related with the history of diabetes, alcohol consumption, hypertension, and undesired lipid profile. Meanwhile waist circumference was a protective factor. In his study, Motala ${ }^{20}$ also mentioned that one of the significant diabetes treatment problems in his country is that only a small proportion of diabetes patients were known DM. The proportion of very high undiagnosed DM in South African rural areas hampers a variety of integrated diabetes program.

In our study we found $33 \%$ of the diabetics were undiagnosed DM. This fact showed that the health service for diabetes in Ende subdistrict was still insufficient. Not only the diagnosis and screening 
Table 5. Diabetes based on HbAlc level

\begin{tabular}{lcccc}
\hline $\mathrm{HbA}_{1} \mathrm{C}$ & Normal & IFG & IGT & DMT2 \\
\hline$<6.5 \%(\mathrm{n}=287)$ & $185(64.5 \%)$ & $89(31.0 \%)$ & $33(11.5 \%)$ & $13(4.3 \%)$ \\
$6.5-8 \%(\mathrm{n}=16)$ & $1(6.3 \%)$ & $11(68.8 \%)$ & $3(18.8 \%)$ & $4(25.0 \%)$ \\
$>8 \%(\mathrm{n}=35)$ & $14(40.0 \%)$ & $10(28.6 \%)$ & $4(11.4 \%)$ & $11(31.4 \%)$ \\
\hline
\end{tabular}

problems, implementation of integrated services (medication, diet, physical activities, and education) carried out in rural areas were scarce. A survey on 40 diabetics in Saumlaki Health Center, West Southeast Moluccas, another remote rural area, reported that all patients never got complete education from health experts, only 4 subjects $(10 \%)$ have sufficient knowledge about diabetes, and only 8 subjects (20\%) who conducted the blood glucose level tests regularly. ${ }^{21}$ Majumdar et $\mathrm{al}^{22}$ and Johnson et $\mathrm{a}^{23}$ found out that with the procurement of integrated intervention (medical specialist team, nurses, pharmacists, dietitian, and diabetes educator) regularly provided to rural areas, will significantly increase glycemic-cardio-metabolic control (blood pressure, HbAlc, and lipid profile).

In the context of diabetes health service in rural areas, the role of primary physicians is very important..$^{21-24}$ It is very difficult to find specialist in rural areas. However, not all general practitioners are proficient and have enough competency in providing holistic and comprehensive diabetes service. ${ }^{23}$ All of these problems lead to sub-optimal diabetes health services in rural areas.

\section{Population studies on diabetes in Indonesia}

There are five important population studies conducted across Indonesia concerning diabetes and risk factors; diabetes study at Koja Utara (Tanjung Priok-North Jakarta-1982), ${ }^{8}$ diabetes study at Kayu Putih (East Jakarta-1993), ${ }^{9}$ diabetes study at Depok (South Jakarta-2001), ${ }^{11}$ diabetes study at Singaparna, Bandung, ${ }^{12}$ and diabetes study at Tana Toraja, South Sulawesi. ${ }^{14}$

The diabetes studies at Koja Utara and Kayu Putih were carried out in urban area, meanwhile Depok study was a sub-urban-area study (although at present has become an urban area), however some variables studied, have similarities with Ende Diabetes Study. In this Ende Diabetes Study, the prevalence of diabetes was 2\% (fasting or post glucose load criteria),1.61\% using fasting blood glucose criteria and $1.57 \%$ using post glucose load criteria ), IFG 6.2\%, and IGT 2.2\%. These figures was not very different from the prevalence of diabetes in East Nusa Tenggara reported in the National Basic Health Study 2007 i.e. 1.8\%, ${ }^{6}$ and also from Koja
Utara in 1981, showing the prevalence of diabetes $1.63 \%$ and IGT $3.7 \%$. The present prevalence of diabetes in rural areas in East Nusa Tenggara is similar to the prevalence of urban area (Jakarta) 30 years ago. Meanwhile, the prevalence of IGT was also higher than diabetes on the two populations.

In this study, the proportion of diabetes among women was higher $(13.95 \%)$ than men $(4.7 \%)$. The proportion of diabetic women was almost the same as men in Koja Utara study. The difference of prevalence between sexes and the influence of sex in DM needs more particular investigation. As an average in Indonesia, female sex has a higher risk to have diabetes than male counterpart (OR 1.3, 95\% CI 1.2-1.4). ${ }^{25}$

Compared to sex, age plays a more important role as a diabetes risk. Both this study and the one at Koja Utara, revealed that there was an increase of prevalence of diabetes and IGT for people with higher age. At Koja Utara, the highest prevalence of diabetes was found in the 55 - 64 years age group. While at Ende Diabetes Study, the proportion of diabetics increased linearly according to the increasing age, starting from the age of 35 year (3.4\%) to $9.4 \%$ among $45-54$ years age group, and reach its peak also on age $55-64$ year (19.4\%). In the 64-75 years age group the age specific prevalence of DM was low. It was probably due to the smaller number of the respondent in this age group. Many of them might have died from other diseases. The life expectancy among Indonesian is less than 65 years. There is no diabetics in the age $<35$ year and $\geq 75$ year. Age is a risk factor which need to be taken into account since in various diabetes studies across the world, age is a significant risk factor. ${ }^{5,26}$ Data from Indonesia also mentioned that age was also closely related with prevalence of diabetes and IGT.

This study found that the prevalence of IFG, IGT, and diabetes reach its peak on population with IMT $\geq$ 25 (obesity) compared to overweight, normoweight or underweight. Similar finding was also found in the Koja Utara study, where a considerable part of the diabetics were in the obese group. The Kayu Putih study found the similar trend of BMI distribution among the dyslipidemic respondents. In the dyslipidemic group, the majority of the subjects 
(54.5\%) were obese with IMT $\geq 25 \mathrm{~kg} / \mathrm{m}^{2}$. Obesity itself is closely related to diabetes in various studies, both domestic and foreign countries. ${ }^{5,17,26-29}$ In a study conducted by Aspray, ${ }^{29}$ the difference of prevalence of diabetes between the urban and rural communities in Tanzania (Africa) could be explained by the presence of difference of obesity level between both populations. While in Indonesia, Mihardja found out that obesity was closely related with diabetes and IGT (OR 1.9 95\% CI 1.7-2.1). ${ }^{25}$

In conclusion, prevalence of diabetes in Nangapanda population was $2 \%$ (using fasting or post glucose load), and $1.56 \%$ using only post glucose load criteria, while the prevalence of IGT were $2.2 \%$ and IFG $6.2 \% \%$ respectively. Using the $\mathrm{HbA} 1 \mathrm{c}$ criteria, the prevalence of diabetes was $2.83 \%$ which should be elaborate further with future study.

Combining with results of other studies made in Indonesia, the prevalence of diabetes in rural areas is still lower than in urban areas. In order to have a thorough comprehension of the increase rate of the prevalence, serial studies should be carried out to compare the increase rate of diabetes prevalence between urban areas and rural areas.

\section{Acknowledgments}

We would like to express our gratitude to Research and Society Services Directorate, Universitas Indonesia, for the grant to finance the study, Division of Metabolic Endocrinology, Department of Medicine, Faculty of Medicine, Universitas Indonesia for support, Nutrition Department Cipto Mangunkusumo Hospital, Department of Clinical Pathology FMUI for collecting data (nutrition anamnesis and laboratory). We thank the study team from Department of Parasitology FMUI for their tools, infrastructure, and study sample framework; as well as Health Services of Ende District, Ende Public Hospital, Nangapanda Public Health Center team, and the administrative staffs of Subdistrict Nangapanda for all their help and participation during the execution of the study in the field.

\section{REFERENCES}

1. Wild S, Roglic G, Green A, et al. Global prevalence of diabetes. Diabetes Care. 2004;27:1047-53.

2. International Diabetes Federation. IDF Diabetes Atlas. 4th ed. Brussels; IDF, 2009.

3. Zimmet P. Asia - the epicenter of the global diabetes epidemic: its history, progression, and prevention. Abstract Book of $8^{\text {th }}$ International Diabetes Federation - Western Pacific Region Congress (IDF WPR Congress), Busan, Korea; 2010.
4. Mohan V, Mathur P, Deepa R, et al. Urban rural differences in prevalence of self-reported diabetes in India - the WHOICMR Indian NCD risk factor surveillance. Diab Res Clin Pract. 2008;80:159-68.

5. Al-Nozha M, Al-Maatouq M, Al-Mazrou YY, et al. Diabetes mellitus in Saudi Arabia. Saudi Med J. 2004;25:1603-10.

6. Badan Penelitian dan Pengembangan Kesehatan. Riset Kesehatan Dasar 2007. Departemen Kesehatan Republik Indonesia; 2008. Indonesian.

7. Yunir E. Prevalensi diabetes pada lima wilayah perkotaan di Jakarta. Buku Hasil Penelitian Penyakit-penyakit Perkotaan di Jakarta. Jakarta: Pusat Penerbit Ilmu Penyakit Dalam; 2006. Indonesian.

8. Waspadji S. Diabetes Melitus di Kelurahan Koja Utara, Tanjung Priok [thesis]. Mount Pleasant (MI): Universitas Indonesia; 1984. Indonesian.

9. Waspadji S, Suyono S, Sukardji K, et al. Pengkajian status gizi - studi epidemiologi penelitian di Kayu Putih, Pulo Gadung. Jakarta: Balai Penerbit FKUI; 2003. Indonesian.

10. Perkumpulan Endokrinologi Indonesia. Konsensus pengelolaan diabetes melitus di Indonesia. Jakarta: PB PERKENI; 2006. Indonesian.

11. Yunir E, Waspadji S, Rahajeng E. The pre-diabetic epidemiological study in Depok, West Java. Acta Med Indones- Indones J Intern Med. 2009;41:181-5.

12. Rusli RMA. Diabetes melitus di Singaparna, Kabupaten Bandung, Jawa Barat [dissertation]. Mount Pleasant (MI): Universitas Padjajaran; 1995. Indonesian.

13. Suastika K. Diabetes melitus di Desa Sangsit, Singaraja, Bali. Unpublished data; 2002. Indonesian.

14. Adam J. Diabetes melitus di Tana Toraja, Sulawesi Selatan. Unpublished data; 2001. Indonesian.

15. West K. Epidemiology of diabetes andit's vascular lesions. New York: Elsevier; 1978.

16. International Diabetes Federation. Global guideline for type 2 diabetes. Brussels: IDF; 2005.

17. Engelgau MM, Thompson TJ, Herman WH, et al. Comparison of fasting and 2-hour glucose and HbAlc levels for diagnosing diabetes; diagnostic criteria and performance revisited. Diabetes Care. 1997;20:785-91.

18. Syeed MA, Mahtab HM, Khanam PA, et al. Diabetes and impaired fasting glycemia in a rural population of Bangladesh. Diabetes Care. 2003;26:1034-9.

19. Balagopal P, Kamalamma N, Patel TG, et al. A communitybased diabetes prevention and management education program in a rural village in India. Diabetes Care. 2008;31:1097-106.

20. Motala AA, Esterhuizen T, Gouws E, et al. Diabetes and other disorders of glycemia in a rural South African community. Diabetes Care. 2008;31:1783-8.

21. Pramono LA, Halim L, Ratuanak J, et al. Pasien diabetes di Saumlaki, Kabupaten Maluku Tenggara Barat: karakteristik, gaya hidup, pengetahuan, dan aspek pengobatannya. Unpublished data; 2010. Indonesian.

22. Majumdar SR, Guirguis LM, Toth EL, et al. Controlled trial of a multifaced intervention for improving quality of care for rual patients with type 2 diabetes. Diabetes Care. 2003;26:3061-6.

23. Johnson JA, Eurich DT, Toth EL, et al. Generazability and persistence of a multifaceted intervention for improving quality of care for rual patients with type 2 diabetes. Diabetes Care. 2005;28:783-8. 
24. Porterfield DS, Kinsinger L. Quality of care for uninsured patients with diabetes in a rural area. Diabetes Care. 2002;25:319-23.

25. Mihardja L, Delima, Siswoyo H, et al. Prevalence and determinants of diabetes mellitus and impaired glucose tolerance in Indonesia. Acta Med Indones. 2007;41:169-74.

26. Dewapura N. Diabetes melitus in Samoa: an epidemiological and quality of care review. Samoa Med J. 2009;1:24-7.
27. Melidonis A, Tournis S, Kompoti MG, et al. Increased prevalence of diabetes mellitus in a rural Greek population. Rural and Remote Health. 2006;6:1-8.

28. Dabney B, Gosschalk A. Diabetes in rural America: a literature review. Rural Healthy People. 2010;57-72.

29. Aspray TJ, Mugusi F, Rashid S, et al. Rural and urban differences in diabetes prevalence in Tanzania: the role of obesity, physical inactivity, and urban living. Trans Soc Trop Med Hygiene. 2000;94:637-44. 